\title{
Bireysellik, Belirsizlik ve Güvensizlik Bağlamında Ailenin Dönüşümü ve Türkiye’deki Yansımaları
}

\author{
The Transformation of the Family in the Context of Individuality, Uncertainty and Insecurity and \\ its Reflections in Turkey
}

\author{
İlknur Beyaz Özbey*
}

\begin{abstract}
In today's societies, the family institution is seriously questioned by decreasing marriages, increasing divorce rates, domestic violence, women's murders, and sexual abuse becoming more visible. Beyond this questioning, the family has been found to be at the target of individualization, uncertainty and insecurity, which puts the family at risk. In this sense, the main subject of the study is the situation at the risk of today's family. The move away from traditional values and modernization characterized by the contact of family institution spends what kind of transformation today, the role of this transformation within the framework of family members and the status of how it is characterized, the family perspective of how it affects the future of the family, globalization risks of the family institution how it affects the direction and these developments to Turkey in what way This study is the main problematic of this study. In this problematic context, it has been observed that the family and the indisputable roles and statuses that are blessed within the framework of traditional values are deconstructed in today's world. Increased individualization caused distance in individuals against the family institution, unstable associations and ignoring the values contained in the family. It is understood that trust-based and long-term marriages gradually weaken, whereas today's marriages appear to be short-term and outdated, imprisoning the family in a trust-insecurity dilemma. Characterized by individuality and insecurity, the family institution, the marriage process and the responsibilities and roles that sustain marriage are ultimately uncertain, and from this perspective, it is seen that today's family is at risk. The transformation of the family in Turkey, individualisation is not free from risks posed by insecurity and uncertainty.
\end{abstract}

Structured Abstract: Individuality, which is the most important benefit of modernity, has an important share in facing risks. Living in a world risk society means that we will or will face risks that previous generations did not. The risks, which were once an account issue, are now out of the account issue and removed it from a positive belief such as estimating the risks. Moreover, the risks contained within the individual decision mechanism create an insecure environment and threaten humanity seriously. Global risks threaten not only by their ecological, economic or political dimensions, but also by their social consequences. One of these areas is the risks that will arise in the change of the family.

\footnotetext{
* Dr. Öğr. Üyesi, Artvin Çoruh Üniversitesi, Fen-Edebiyat Fakültesi, Sosyoloji Bölümü. Asst. Prof. Dr., Artvin Coruh University, Fakulty of Science and Letters, Department of Sociology. ORCID 0000-0001-9809-9085

ilknurbeyaz087@gmail.com

Cite as/ Atıf: Beyaz Özbey, İ. (2020). Bireysellik, belirsizlik ve güvensizlik bağlamında ailenin dönüşümü ve Türkiye'deki yansımaları. Turkish Studies $\quad-\quad$ Social, $15(4), \quad$ 1737-1751.
} https://dx.doi.org/10.29228/TurkishStudies.43322

Received/Geliş: 03 May/Mayıs 2020

Accepted/Kabul: 20 June/Haziran 2020

Copyright $($ INTAC LTD, Turkey

Checked by plagiarism software

Published/Yayın: 25 June/Haziran 2020

CC BY-NC 4.0 
Family life has a certain order within the framework of certain rules, traditions, customs. Individuals living in the family acquire roles and status within the framework of the rules. In the family, which has biological, psychological, sociological and economic duties, roles and duties are based on a system where they are known and applied by everyone. But now it seems that the family has lost its former strength, charm and holiness. Modern social life forms a society that does not depend on traditions, habits, customs and beliefs. Breaking with traditional bonds has given the individual the opportunity to get rid of old controls. It is a fact that the type of family that has been transformed from extended family to nuclear family has been transformed. Contrary to a structure that everyone previously accepted, as in traditional families, the duties and responsibilities taken during the marriage process is a situation where an agreement can be reached by talking. Along with the change of the relationship processes in the family, there are important changes in the family institution. In today's societies where individuality is dominant, besides the individual decisions taken to start a family, increases in divorce rates and experiences of living together rather than starting a family are high.

In today's family, where individuality is dominant, it is seen that stability and trust have become a sought-after situation, and uncertainty and incalculable situations prevail. As a matter of fact, it is seen that the risks, uncalculated situations, uncertainties and trust problems seen on the technological, economic and abstract systems of the risk society also have social dimensions. Especially in today's family, which has been transformed by individualization, there is uncertainty, calculability, individuality and trust problems. The family's existence continues without controversy, but the family, which survived traditional bonds, is located within the boundaries of individuality and individual decisions. These limits create a slippery ground for the family institution and individuals. It is obvious that the slippery ground negatively affects the family institution, the life of the marriage process and marriage relations. In other words, shaping the family institution and the marriage process within the framework of individual decisions and responsibilities instead of traditional values and attitudes, shaping the future of the family institution within the framework of the concepts of trust, uncertainty and incalculable. The family institution, the marriage process and the structure of the relationships, which are shaped within the framework of individual decisions and attitudes, are located on a slippery ground, and the life-long trust environment of the family takes its place in a structure that is short and non-binding. Therefore, this distrust is obviously a door to the risks of globalization for the family institution. While the risks of globalization follow the course of development at different stages for each institution and every society, the future of the family institution, the risk dimension differs by following the course of development of each society according to the internal dynamics of each country. Although the family institution in Turkey take place in a location that maintains the sanctity, the questioning of the individuality of the slippery floor in the family's inner dynamism, it is a fact that opened the door to thaw. Even if marriage is carried out, it is not possible to talk about prolonged marriages due to the wearing of trust environment within the framework of individual decisions. Their experiences of living together as an alternative to the family institution gradually eliminates the necessity of marriage and causes it to take its share from the risks of globalization.

Keywords: Individuality, Uncertainty, Insecurity, Risk, Family.

Öz: Günümüz toplumlarında aile kurumu, evliliklerin azalması, boşanma oranlarının artması, aile içi şiddetin, kadın cinayetlerinin, cinsel istismarın daha fazla görünür hale gelmesiyle ciddi anlamda sorgulanmaktadır. $\mathrm{Bu}$ sorgulamanın ötesinde aile, bireyselleşmenin, belirsizliğin ve güvensizliğin hedefindeki yer aldığı ve bunun da aileyi risk altına sürüklediği görülmüştür. Bu anlamda çalışmanın temel konusunu, günümüz ailesinin risk altındaki durumu oluşturmaktadır. Geleneksel değerlerden uzaklaşan ve modernleşmenin karakterize ettiği aile kurumunun günümüzde nasıl bir dönüşüm geçirdiği, bu dönüşüm çerçevesinde aile üyelerinin rol ve statülerinin nasıl karakterize edildiği, aileye bakış açısının ailenin geleceğini nasıl etkilediği, küreselleşmenin risklerinin aile kurumunu ne yönde etkilediği ve bu gelişmelerin Türkiye'ye ne şekilde yansıdığı bu çalışmanın temel sorunsalını oluşturmaktadır. Bu sorunsal bağlamında, geleneksel değerler çerçevesinde kutsanan aile ve tartışmasız kabul edilen rol ve statülerin günümüz dünyasında yapıbozumuna uğratıldığı görülmüştür. Artan bireyselleşmenin bireylerde aile kurumuna karş1 mesafe oluşturmalarına, istikrarsız birlikteliklere ve ailenin içerdiği değerlerin yok sayılmasına neden olmuştur. Güvene dayalı ve uzun süreli evliliklerin giderek zayıflaması, buna karşın günümüz evliliklerinin kısa süreli ve modası geçmiş gibi görünmesinin aileyi güven-güvensizlik ikilemine hapsettiği anlaşılmıştır. Bireysellik ve güvensizlik çerçevesinde karakterize edilen aile kurumu, evlilik süreci ve evliliği ayakta tutan 
sorumluk ve roller en nihayetinde belirsizlik arz etmekte ve bu çerçeveden bakıldığında günümüz ailesinin risk altında olduğu görülmektedir. Türkiye'de ailenin dönüşümü, bireyselleşmenin, güvensizliğin ve belirsizliğin oluşturduğu risklerden bağımsız değildir.

Anahtar Kelimeler: Bireysellik, Belirsizlik, Güvensizlik, Risk, Aile.

\section{Giriş}

Temellerini Aydınlanmanın oluşturduğu modern dünya, bilimin, aklın, teknolojinin gelişmesiyle birlikte dünya üzerinde kontrol edilebilirlik derecesi artmıştır (Tomlinson, 2004). Geleneğin modernleşmesi ile sanayi toplumunun modernleşmesi arasındaki ayrım gereğince bilim, uygulama ve kamusal alan ilişkisinde birbirinden farklı iki durum söz konusudur: basit ve dönüşlü bilimselleşme. Bilim ilk önce verili bir doğa, insan ve toplum dünyasına uygulanır. Dönüşlü evrede ise bilimler kendi ürünleriyle, eksiklikleriyle ve ortaya çıkan sorunlarıyla yüzleşir (Beck, 2011: 233). Sorunları içerisinde başat konuma sahip olan risk kavramı esasında modernizme bağlı bir kavram olarak karşımıza çıkmaktadır. Risk eski tehlikelerin aksine, modernleşmenin tehditkâr kuvveti ve bunun belirsizliğinin küreselleşmesi ile ilişkili olan sonuçlardır (Giddens, 2013b). Modernleşmenin üretmiş olduğu riskler, Ulrich Beck'in deyimiyle risk toplumu aşamasını oluşturmaktadır. Risk toplumu esasında, bilimin, teknolojinin üretmiş olduğu risklerin ve tehlikelerin kontrol ya da güvence altına alınabilirlilik durumunu aştığı anda ulaşılmaktadır. Öyle ki, söz konusu riskler sadece ekonomik, ekolojik ve siyasi boyutları olmayan toplumun hemen hemen bütün boyutlarını aşamalı bir şekilde etkisi alan bir yapıya sahiptir.

Batı'da meydana gelişmeler göz önüne alındığında ailenin bu değişmelerden etkilenmemesi imkansızdır. Sanayi devrimiyle birlikte aile iki açıdan etkilenmiştir. İlkin, ailenin işlevlerinde meydana gelen değişim oluşturmaktadır. Kırsal alandan kentlere doğru göçler, sanayinin işgücü ihtiyacını karşılamıştır. O güne kadar, sınırlı işbölümü, hane halkı emeği ve geçimlik ekonomi söz konusuyken, sanayileşmeyle birlikte yerini ücretli emeğe bırakmıştır. İkinci olarak da, toplumsal mobilitiye sahip olmayan, geleneksel değerler ve tanrı buyruklarıyla karakterize edilen aileler zamanla organik bağlara dayalı bir topluma, toplumsal hareketliliğe bırakmıştır (Duman, 2012). Modernleşmenin etkileri üzerine geleneksel aileden çekirdek aileye doğru bir geçiş süreci yaşanmıştır. Bu geçişin özünü aile üyelerinin, bireylerin geleneksel bağlardan kurtulup, kendi bireysellikleriyle toplumsal hayatta var olma durumları oluşturmaktadır.

Toplumun ve toplumsal kurumların ürettiği riskler, öznelleşme ve bireyselleşmenin ön ayaklarını oluşturmaktadır. Birey için belirleyici olan kurumsal konumlar, artık sadece bireyin başına gelen olaylar ve koşullardan ibaret değil, bilakis kendi verdiği kararların sonuçlarıdır. Dolayısıyla bireyin söz konusu konumları böyle görmesi ve benimsemesi gerekiyor. Ortaya çıkan riskler öncelikle tanrı kaynaklı ya da doğal felaketler olarak algılanır ve bireysel sorumluluk söz konusu değildi. Ama bugün bir sınavı geçememekten işsiz kalmaya ya da boşanmaya kadar pek çok olay kişisel başarısızlık olarak görülüyor. Bireyselleşmiş toplumda riskler niceliksel olarak artmakla kalmaz niteliksel bakımdan yeni kişisel riskler, seçilmiş ve şahsi kimliği değiştirmiş riskler de doğar (Beck, 2011: 207). Bireyleşmenin başıboş olduğu dünyamızda ilişkiler iki ucu keskin kılıç gibidir. Akışkan bir modern yaşam çerçevesinde ilişkiler, en canlı, en dayanılmaz, en derinden hissedilen ve en yaygın müphemliklerin tezahürüdür belki de (Bauman, 2012a: 9). Bireyselleşmenin etkisi altında yaşayan bireyler, kendi öznelliklerinin başat konumda olduğu toplumsal bir hayat karakterize etmektedirler. Söz konusu hayat içerisinde, bireysel karar ve sorumlulukları altında eylemlerde bulunup toplumsal hayatı deneyimlemektedirler. Bireyselliğin toplumsal sonuçlarına odaklanıldığında ise, belirsizlik, hesaplanamazlık ve güvensizlik gibi risk toplumunun başat kavramları karşımıza çıkmaktadır. Söz konusu kavramlar toplumun hemen hemen her kurumunda görüldüğü gibi aile kurumunu da etkisi altına aldığı aşikârdır. 
Geleneksel değerlerden kopuş, bireysellik üzerine kurulan aile kurumu modernleşmenin üretmiş olduğu risklerden etkilenmektedir. Aile kurumuna ait normlar, adetler, gelenekler giderek soluklaşarak zayıflamaktadır. Geleneksel değerlerin hakim olduğu dönemlerde üzerinde anlaşmaya varmayacak şekilde bilinip, kabul edilen kurallar, günümüz ailesinde tartışmaya açılmakta ya da anlaşma konusu yapılmaktadır. Bu nedenle de üzerine anlaşma yapılan aile kurumu, evlilik sürecinde gerçekleşen rol ve statüler, sürekli olarak yeniden feshedilebilir bir yapı sergilemektedir. $\mathrm{Bu}$ yap1 içerisinde her şey tartışılabilir, yıkılabilir, bireysel karar ve sorumluluklar çerçevesinde yeniden kurulabilmektedir. Dolayısıyla bireysellik çerçevesinde karakterize edilen aile, uzun sürmeyen yapısı ile güvensizlik arz etmektedir. Risk toplumu çerçevesinde ailenin geleceği tartışılır bir konu haline gelmektedir. $\mathrm{Bu}$ anlamda çalışmanın temel konusunu, günümüz ailesi oluşturmaktadır. Geleneksel değerlerden kopan ve modernleşmenin karakterize ettiği aile kurumunun nasıl değiştiği, bu değişim çerçevesinde aile üyelerinin rol ve statülerinin nasıl karakterize edildiği, söz konusu rol ve statüler bağlamında ailenin geleceğinin nasıl etkilendiği ve küreselleşmenin üretmiş̧ olduğu risklerin aile kurumunu ne yönde etkilediği çalışmanın temel sorunsalını oluşturmaktadır. Başka bir ifadeyle, modernleşmenin dönüştürdüğü aile kurumunda, bireysellik ve güvensizlik gölgesinde nasıl bir risk çerçevesi oluştuğu ve söz konusu durumların Türkiye'deki aile kurumuna yansımaları anlaşılmaya çalışılmaktadır.

\section{Modernlik ve Risk Toplumu}

Modernlik, içinde insanların kendi yaşamlarını kavradıkları bir durumdur. Aslında modernlik ortaklaşa hayatın nasıl yönetileceği, insan gereksinmelerinin nasıl karşılanacağ geçerli bilginin nasıl kurulacağı sorularına atıfta bulunmaya ihtiyaç duymaktadır (Wagner, 2013: 2). Modernliğin ortaya çıkışı her şeyden önce modern ekonomik düzenin, kapitalist ekonomik düzenin ortaya çıkışıdır. Ama modern toplum aynı zamanda farklı bir örgütlenme yapılarını da içerir. Bunun temelini bilgi oluşturmaktadır. Teknolojik gelişmelerin yaşanması ise toplumların gelişmesinde ve değişmesinde çok önemli bir etkiye sahiptir (Steger, 2004: 133). Modernlik salt değişim ya da olaylar silsilesi değildir; akılcı, bilimsel, teknolojik ve idari etkinliğin ürünlerinin yaygınlaştırılmasıdır. Modernlik fikri toplumun merkezindeki Tanrı'nın yerine bilimi koyarak, dinsel inançlara ancak özel yaşam dâhilinde bir yer bırakır. Modern bir toplumdan söz edebilmek için bilimin teknolojik uygulamalarının olması yeterli değildir (Touraine, 2012: 25-26). ). Daha ayrıntılı olarak baktığımızda bu kavram dünyaya karşı belirli yerleşik tutumları, insanın müdahalesiyle şekil almaya açık bir dünya fikrini; ekonomik kurumların karmaşık bir bileşimini, özellikle endüstriyel üretim ve pazar ekonomisini; ulus-devlet ve kitle demokrasisi dahil olmak üzere belirli siyasal kurumları göstermektedir. Büyük ölçüde bu niteliklerin bir sonucu olarak modernlik, daha önceki herhangi bir toplum tipine göre çok daha dinamik bir yapıya sahiptir (Giddens ve Pierson, 2001: 83). Modernlik, esasında zincirin halkaları gibi birbirine bağlı sac ayaklardan meydana gelen değişimin ifadesidir. Teknolojik, ekonomik, siyasi ve kültürel anlamda gerçekleşen değişimler, toplumsal olarak önemli dönüşümlerin kaynağını oluşturmaktadır.

Modernlik, geleneklere, adetlere, alışkanlıklara, rutinlere, beklentilere ve inançlara bağlı olmayan bir toplumsal yap1 karakterize etmektedir. Modernliğin en önemli farklılı̆̆ı, daha önce var olan şeylerin yerinden edilmesidir (Giddens ve Pierson, 2001). Modernliğin gurur, insani eylemle, özellikle de insanın bilimsel-uygulayımsal yaratımlarıyla oluşmuş bir dünyanın kutsallaştırılmasına dayanır. Bu utku zamanla kısmen bir felakete, uygarlık ve insan türü için bir tehdide dönüştügü için bu modernlik anlayışına giderek daha çok karşı çıkılmıştır (Touraine, 2011: 120). Geleneklerin, adetlerin, rutinlerin üzerinde bilimsel eylem ve davranışların yer alması, modernliği oluşturmaktadır. Aynı zamanda bu durum felaket ya da risk olarak kavramsallaştırılan bir durumun önüne geçememiştir. Modernliğin üretmiş̧ olduğu riskler, geçmişte deneyimlenen riskler ile karş1laştır1lamayacak büyüklükte ve mahiyette kendini göstermektedir.

Geçmişteki tehlikeleri, hijyen teknolojisindeki yetersizlikle açıklamak mümkündü. Oysa bugünkü tehlikelerin temelinde sanayideki aşırı üretim vardır. Bu yüzden günümüzdeki riskler ve 
tehlikeler (insanlar, hayvanlar, bitkiler üzerindeki) tehdidin küresel doğası ve modern sebepleri olması bakımından yüzeysel olarak genellikle benzer oldukları Ortaçağ' daki risk ve tehlikelerden ciddi bir şekilde ayrllıyor. Bunlar modernleşmenin riskleridir. Üstelik endüstriyel ilerleme mekanizmasının toptan ürünleri ve mekanizmanın gelişmeye devam etmesiyle sistematik olarak daha vahim bir hele geliyor (Beck, 2011: 25). Küresel düzeyde inşa edilen riskler, ulusal veya devlet tarafından kontrol edilemeyen güvenlik tedbirlerini ve yaşamı tehlikeye atan boyuttadır. Ulrich Beck'in de belirttiği gibi klasik veya eski olarak adlandırılan eski sanayi toplumu kaybolmakta ve yeni bir risk toplumu yaratılmaktadır. Başka bir ifadeyle küresel olarak risk toplumu aşamasından geçtiğimizi söyleyebiliriz (Kovacevic ve Kovacevic, 2017: 38). On sekizinci ve on dokuzuncu yüzyıllarda ekonomik kalkınma süreci, hesaplanamaz riskin varlığını arttırmıştır. $\mathrm{Bu}$ dönemde sanayi ve sermayenin istikrarlı bir şekilde büyümesi, yatırımcıların ve bankacıların faaliyetleriyle riskin ekonomi ile ilişkilendirilmesini sağlamıştır. Yirminci yüzyılın başlarında, kredi ve borç verenler için olası yatırım sonuçlarını tanımlamak için sigorta ve finansta "risk" yaygın olarak kullanılmıştır. Modern zamanlarda risk, ekonomi ile sıkı sıkıya bağlı kalmaktadır (Mythen, 2004: 14). Modernliğin bir sonucu olarak karşımıza çıkan risk, ekonomi ile anılır olmasının yanında, sanayi üretiminin aşırı olması ile doğayı tahrip eden bir yanı da karşımıza çıkmaktadır. Ekolojide meydana gelen hasarlar, esasında riskin sadece ekonomi ile sınırlandırılamayacağı, hemen hemen her alanda karşımıza çıkacağını göstermektedir. Hangi alanda olursa olsun bu aşamada risklerin hesaplanamaz olması, risk toplumunun en önemli özelliklerinden birini oluşturmaktadır.

Risk, geleneksel davranış biçimlerini terk eden ve kendini bizzat problemli bir geleceğe açan bir toplumda merkezi bir terim halini almıştır. Geleceğin doğası gereği bilinemeyeceği ve geçmişten giderek uzaklaştığ 1 kabul edilirken, gelecek yeni bir alana dönüşür. Risk hesaplaması asla tam olmaz, zira nispeten sınırlı risk ortamlarında bile her zaman niyetlenilmemiş ve öngörülemeyen sonuçlar mevcuttur. Kader fikrinin etkisinin kaybolduğu bir ortamda, her eylem hatta yerleşik örüntülere kuvvetle bağlı eylemler prensip olarak risk koşulları temelinde hesaplanabilir. Genel muhtemel bir risk değerlendirme türü, özel sonuçları konusunda fiilen tüm alışkanlıklar ve etkinlikler için yapılabilir. Soyut sistemlerin gündelik hayatı istilası, bilginin dinamik doğasıyla birlikte, risk bilincinin hemen herkesin eylemlerine sızması demektir (Giddens, 2010a: 146). Bu anlamda risk toplumunun diğer özelliği, risklerin hesaplanamamazlığıdır. Kimi çevrelerde, teknik yönetebilirliği olmayan risklerin-en azından bilimsel hesaplama ya da yarg1 kararları bakımından-var olmadığı söyleniyor. Bu hesaplanamaz tehditler birikiyor ve sanayinin her yerde herkese yönelik bir ihsanı olan bilinmeyen bir risk tortusu teşkil ediyor (Beck, 2011: 38). Elli yıl öncesine kadar daha fala güvencesizlik ve belirsizlik içinde hissetmek için çok fazla nedene sahibiz. Esasında söz konusu belirsizliğin eskiye nazaran korkutucu olmasının nedeni, algılanan güçsüzlüğümüzdür (Bauman, 2014b). Hesaplanamazlığın mevcut olduğu durumlar haliyle belirsizlik barındırmakta ve doğal olarak bu belirsizlik, içerisinde ne tür risklerle karşılaşılabileceği müphemlik oluşturmaktadır. Dolayısıyla risk toplumunun en önemli özelliği, karşılaşılacak risklerin belirsizlik ve nihayetinde hesaplanamaz oluşudur. $\mathrm{Bu}$ durum ise, korku ve güven problemini gün yüzüne çıkarmaktadır. Korku ve güven problemi sadece ekonomik, teknolojik, ekolojik vs. durumları kapsamamakta, insanı çevreleyen hemen hemen her toplumsal olayda kendini göstermektedir.

Güven probleminin temel kaynağını oluşturan durum, modernitenin bireycilik ve kapitalist yapısıdır. $\mathrm{Bu}$ anlamda bireylerin aile yaşamından iş yaşamına toplumsal hayatı risk altındadır (Akalın, 2017). Söz konusu risklere ise artık bireylerden bir çözüm yolu bulmaları beklenmektedir. Bunu ise, bireysel seçimleri ekseninde eylemlerinin başarı ve başarısızlığının sorumluluklarını üstlenmeleri istenmektedir (Bauman, 2014b). Toplumsal olarak her alanda karşılaşılabilecek risklere, bireysel çözümler üretilmesi beklenmektedir. Modernliğin üretmiş olduğu risklere karş1 bireysel sorumluluk üst düzeye ulaşmıştır. Teknolojik gelişmeler sayesinde gelişen soyut sistemler ve uzmanlık alanlarında çeşitlilik, karşılaşılabilecek durumlara karşı önlem almada önemli bir 
avantaj sağlamaktadır. Fakat madalyonun öbür yüzüne dikkatimizi yönlendirdiğimizde hangi sorunda, hangi risk durumunda, hangi uzmana başvurulacağ durumu olarak karşımıza çıkmaktadır. Başka bir ifadeyle modernitenin bir sonucu olarak karşımıza çıkan riskler, belirsizlik, güvensizlik ve hesaplanamaz durumları içerirken, aynı zamanda gündelik yaşamda insanları tehdit etmektedir. Üstelik bu durum artık hayatımızın hemen hemen her alanında karşımıza çıkma ihtimali söz konusuyken, aile kurumunun da bundan nasibini almadığını düşünmek imkânsızdır.

\section{Ailede Yaşanan Dönüşüm}

Toplumun en küçük yapı taşı olan aile, birbirine kan bağıyla bağlanan bireylerden oluşan bir topluluk olarak tanımlanabilir. Aile, biyolojik, psikolojik, ekonomik, toplumsal hukuksal vs. işlevleri bulunan bir birim olarak karşımıza çıkmaktadır. Aynı zamanda aile, bireyleri topluma hazırlayan, onlara sosyal kimlik kazandıran ve toplumsallaşma sürecinin önemli unsurlarından biri olan toplumsal bir kurumdur. Toplumun maddi ve manevi değerlerini kuşaktan kuşağa aktaran aile, aynı zamanda bireylerin beslenme, barınma, bakım, sevgi ihtiyacını karşılayarak duygusal gelişim ve bireylerin sosyalleştiği ortamdır. Gerekli fiziksel ve ruhsal ortam oluşturarak aile üyelerine doyum imkânı sağlamaktadır. Toplumun en küçük birimi olması itibariyle hem toplumu etkileyen hem de toplumsal gelişmelerden etkilenen bir kurum olarak karşımıza çıkmaktadır. Dolayısıyla aileyi, toplumsal gelişmelerden bağımsız bir şekilde düşünmek imkânsızdır. Nitekim geniş aileden çekirdek aileye dönüşüm bu durumun en güzel örneğini yansıtmaktadır.

Geniş aile, genellikle kırsal kesimlerde, tarıma dayalı toplumlarda yaygın olan bu aile türünde erkeğin kadın, yaşlının genç üzerinde kesin otoritesi söz konusudur. Yani aile içi ilişkiler eşitlikçi değildir. Bu aile biçiminin yaygın olduğu geleneksel-tarıma dayalı toplumlarda ekonomik üretim aile bazında yapılmakta ve işbölümü-uzmanlaşma düzeyi oldukça düşük ve basit bir teknolojiyi içermektedir. Üyeler arasında ayrım daha çok cinsiyet temelinde yapılır (Karataş, 2011: 93). Geleneksel değerlerin hakim olduğu geniş ailede, bireyin konumu tartışmasız bir şekilde geleneksel değerler tarafından çevrelenmiştir. Bireylerin statüsü ve statülerine bağlı rolleri yine geleneksel değerler çerçevesinde belirlenmiştir. Söz konusu rollere uyum esas alınmaktadır ve rollerin tartışılmasına açık bir kapı bırakılmamıştadır. Geleneksel rol ve statülere uyum, geniş ailenin en önemli özelliği olarak karşımıza çıkarken, toplumsal gelişmelere paralel olarak da değişime uğramaktadır.

Her toplumda farklı aşamalarda gözlemlenen değişim, toplumsal bir gerçeklik olarak karşımıza çıkmaktadır. Söz konusu değişim, diğer kurumları etkilediği gibi aile kurumunu da etkilemektedir. Özellikle ailenin işlevlerinde, yapısında ve aile üyelerinin rollerinde değişiklikler gözlemlenmektedir (Ünal, 2013). Sosyal, siyasal ve iktisadi dönüşümler geleneksel geniş ailenin kentler içerisinde giderek çözünmesi ve kadın-erkek ve evli olmayan çocuklardan oluşan çekirdek aile adı verilen, yaşamsal ihtiyaçlar açısından daha ekonomik bir yaşam tarzını belirleyen bir aile yapısının form bulmasına yol açmıştır. Kent ve köyler arasındaki farklılaşma ve göç dalgası geleneksel geniş ailenin parçalanarak kentlere dağılmasına yol açarken, kent içerisindeki yeni çalışma koşulları ve üretim zincirleri çekirdek aile içerisindeki bireylerin rol ve konumlanışlarını da etkilemiştir. Bununla birlikte kapitalist sistemin devamlılığı açısından oldukça büyük önem taşıyan aile kurumu, geleneksel geniş aile içerisinde yer alan patriarkal ilişkiler zincirini oluşturan bazı kurum ve kültürleri de taşımaya devam etmiş, ancak ailenin geleneksel pek çok fonksiyonu da modern yaşam içerisinde birtakım yeni kurumlara aktarılmıştır (Tekin-Epik, Çiçek ve Altay, 2017: 45). Sanayileşme, şehirleşme, teknolojik gelişmeler, eğitim seviyesindeki artışlar, kadının çalışma hayatına katılımı ile birlikte aile de önemli oranda değişime maruz kalmıştır. Toplumun yaşadığı değişim ve dönüşümden bağımsız olmayan aile de değişime uğramış, geleneksel geniş aileden çekirdek aileye bir dönüşüm gerçekleşmiştir.

Çekirdek aile, anne, baba ve çocuklardan oluşan bir birlikteliktir. Çekirdek ailenin en önemli özelliği, anne ve babanın karşıllklı bağlılığıdır. Bu aile yapısında çocuklar belirli bir yaşa

Turkish Studies - Social, 15(4) 
geldikten sonra aileden ayrılmakta ve kendilerine ait bir aile birlikteliğine geçmektedirler (Bozkurt, 2018). Çekirdek ailede, geleneksel geniş aileye nazaran aynı çatı altında yaşayan üye sayısı daha azdır. Geleneksel değerlerin yerini modern kurum ve değerler almıştır. Nitekim günümüzde çekirdek aile yapısında da önemli değişimlerin yaşandığı görülmektedir. Özellikle boşanma oranlarındaki artışlar, bireysel yaşama deneyimlerinde gözlemlenen artışları aile kurumunun önemli bir dönüşüm yaşadığının göstergesidir.

Aile kurumu temelini aydınlanma felsefesinden alan modern çağın dinamiklerinden etkilenmiştir. Daha önceleri çok güçlü kurum olan aile fonksiyonlarını diğer kurumlara bırakarak daha güçsüz ve daha kırılgan bir kurum haline dönüşmüştür. Aile kurumu modern toplumlarda kolay vazgeçilebilecek kurum haline gelince bunun doğal sonucu olarak boşanmalarda artmıştır (Özkiraz ve İşçi-Baş, 2016: 94). Boşanma oranlarındaki artışlar ve boşanmaya karş1 olumlu tutumların temeli moderniteye dayanmaktadır. Moderniteyle birlikte ortaya çıkan yeni yaşam koşulları, ekonomik durum, sosyal refahın yükselmesi, özellikle kadının daha fazla iş hayatında yer alması ailevi ilişkilerde değişikliğe neden olmuştur. Aynı zamanda modern örgütlerin ortaya çıkması ve ailenin üstlendiği rolleri devralması ile birlikte boşanma oranlarındaki artışlarında önemli nedenler arasında yer almaktadır (Turgut, 2017). Modern toplum, eylemlerinin bilincinde olan bireylerin yaşadığı bir toplumdur. Bu gelişmenin yapısal farklılaşma süreciyle yakından ilişkilidir. Yüksek düzeyde farklılaşmış modern toplumlarda çok farklı biçimlerde ve çok sayıda bireylerle, gruplarla ve örgütlerle ilişki kurma imkânı vardır. Bu nedenle modern birey, görece büyük bir bağımsızlık ve eylem özgürlügüne sahiptir. Bu ortam modern insana özellikle sosyal ilişkilerin hiç kimseye ya da hiçbir şeye bağımlı olmadan düzenlendiği durumlarda, büyük bir özgürlük hissi vermektedir. Kişi kendisini, kendi yazgısının efendisi ve sahibi olarak görmektedir. Bu zihniyet modern insanların artık geleneksel kurumların (evlilik, ebeveynlik, kilise vs.) etkisinde değil, kişisel duygularının ve hislerinin etkisi altında düşünmeleri biçiminde tezahür etmektedir (Loo ve Reijen, 2006: 46). Modernlik, toplumsal kurumları değiştirip yeni bir dünya karakterize ederken; onlarla iletişim halinde olan bireyin dünyasını da değiştirmiştir. Geleneklerin, adetlerin, rutinlerin etkisinden kurtulan birey, modern toplumda sosyal ilişkilerini hiçbir şeye bağlı olmadan gerçekleştirmektedir. Dolayısıyla modernlik hem toplumsal hem de bireysel anlamda kökten bir dönüşümün adresi olarak karşımıza çıkmaktadır.

Toplumsal düzeyde gerçekleşen değişimler aile kurumunu da etkileyerek önemli dönüşümlerin yaşanmasına neden olmuştur. Üretim biçiminin değişimi, teknolojik gelişmeler, sosyal refahın yükselmesi, emek piyasasında kadının yer alması, eğitim oranlarındaki artışlar genel olarak aile üyelerinin konumlarında değişimin ana noktasını oluşturmaktadır. Geleneksel ve dini değerlerin yerini modern değerlerin aldığı günümüz dünyasında çekirdek aile başat konumda olmasına rağmen, boşanma oranlarındaki artışlar dikkati çekmektedir. Ailenin kendine ait işlevlerinin, aile üyelerinin statü ve rollerinin, aileye ait değerlerin sorgulandığı noktada boşanma kaçınılmaz olurken, bir aile kurma gerekliliği bireysel bazda zayıflamaktadır. Dolayısıyla çekirdek aile yerine bekâr, birlikte yaşamayı tercih eden ya da boşanmış bireylerin varlı̆̆ gün yüzüne çıkmaktadır. Bu anlamda zamanla çekirdek ailenin karşı karşıya kaldığ 1 yeni formlar ortaya çıkmaktadır. Söz konusu durum ise gelinen noktada, ailenin geleceğinin tartışılmasına, gelecekte nasıl bir form alacağı, aile kurumunun ne tür riskleri barındırdığ sorusunu akıllara getirmektedir.

\section{Günümüzde Ailenin Risk Toplumu Bağlamında Değerlendirilmesi}

Günümüzün toplumlarındaki aile sistemi hızlı bir değişim süreci yaşamaktadır. Bu değişim süreci aynı zamanda bir kriz görüntüsü sergilemektedir. Ortaya çıkan bir görünüm, aileyi oluşturan rollerin yeni bir organizasyona ihtiyacın bulunduğunu gündeme getirmektedir (Akyüz, 2008: 139). Günümüzde iyi işlerde çalışan kadınlar ve erkekler ekonomik açıdan aileden bağımsızlar. Kadın ve erkeğin beraberliği feodal hiyerarşilerde olduğu gibi artık herhangi bir siyasal amaca, hanedanlıkların sürdürülmesine ya da mülk edinmeye hizmet etmiyor. Miras alınan ve doğal kabul edilen bağlar gevşemiş ve takım halinde çalışan çift artık ayrıcalıklı bir konuma oturmuş 
görünüyor. Kısacası sağlam temelli ve düzenli olan her şey giderek kayboluyor. Aşk evliliği sanayi devriminden beri var olmuştur ve onun buluşudur. Toplumsal gerçekler tam tersini ileri sürmesine karş1lık böyle bir evlilik en fazla arzu edilen hedef olarak kabul edilmektedir. Evlilik, zenginlik ve gücü öteki nesillere geçirmenin bir yöntemi iken sadece duygusal ilgi ve insanın kendini bulma arzusu ile beslenen bugünkü konuma doğru gösterdiği başkalaşım sonucunda istikrarını kaybetmiştir (Giddens, 2013b: 191). Aile içerisinde görülen bu kriz durumunu ya da sorun yumağını aileye özgü durum olarak görmemek gerekmektedir. Gözlemlenen olumsuz durumların, genel toplumun yapısı ve işleyişiyle çok yakından bağlantılı olduğu açıktır. Ailenin işleyişi ve yapısı çok sağlam temeller üzerinde kurulmuş olsa da toplumdaki hılı ve köklü değişimler karşısında direnç göstermesi düşünülemez. Esasında bu durum modernliğin üretmiş olduğu risk ya da sorunların, toplumsal ve en nihayetinde bireysel sonuçları olarak karşımıza çıkmaktadır.

Eylemlerimizin sonuçlarını, niyetlerimizi ve kullandığımız metotların ne kadar altında tutmaya çalışırsak çalışalım, genelde beklentilerimizden çok farklı sonuçlanırlar ve önceden hangi hamleyi yapacağımızın ne zaman ve nasıl farklı sonuçlar doğuracağını kestirmemizi imkânsız k1larlar (Bauman, 2014b: 127). Bu noktada özellikle Beck'in üzerinde durduğu husus, toplumsal yaşamda oluşan riskleri bireylerin tam manada kontrol edememesi sonucu ortaya çıkmaktadır (Akalın, 2017). Risk toplumu esasında, modernliğin üretmiş olduğu belirsizlik ve hesaplanamaz durumları barındırmaktadır. Sanayi sistemleri, teknolojik gelişmeler, uzmanlık alanlarının artması, görünüşte büyük avantajları bulunsa da, madalyonun öteki yüzünde geri döndürülemez ve eski dönemlerle kıyaslanamayacak riskleri de üretmiş bulunmaktadır. Modernliğin üretmiş olduğu riskler sadece teknolojik, ekonomik ya da siyasi anlamda sonuçları ile değil, toplumun hemen hemen her kademesinde karşımıza çıkmaktadır. Bu alanlardan birisini de aile oluşturmaktadır. Bireyselliğin oluşturmuş olduğu toplumsal sonuçlar, ilişkilerde ve evliliklerde yaşanan değişim, ailenin geleceğinin sorgulanmasına neden olmaktadır. Başka bir ifadeyle bireyselleşmenin arttığı modern toplumlarda bireysel kontrol mekanizmalarının zayıflaması, risklere karşı bireylerin tam manada kontrolünün bulunmaması olası bir durumdur. Dolayısıyla belirsizlik ve hesaplanamaz durumların gölgesi altında aile de olumsuz yönde etkilenmektedir. Bu durum ise risk toplumunun bir boyutunu oluşturduğu görülmektedir.

\section{Geleneğin Dönüşümünde ve Bireysellik Bağlamında Aile}

Aile, toplumun en küçük yapısı olması itibariyle, kendi içerisinde de özel bir gelenek oluşturmaktadır. Kadın-erkek ilişkilerinin şekillendiği bu alanda aileye daha sonra katılan üyeler arasındaki ilişkileri de karakterize etmektedir. Sorumluluk duygusuna dayanan ve cemaatsel ilişkilerle şekillenen bu özel alanda, insana dair ne varsa bu alan içerisinde paylaşılmaktadır (Turgut, 2017). Aile içerinde yer alan geleneksel sistem, aile üyelerinin konumlarını ve buna bağlı rollerini belirlemiş bulunmaktadır. Aile üyeleri, geleneksel sistem çerçevesinde düşünmekte ve tutumlarını sergilemektedir.

Geleneksel toplumlarda, bireyler geleneksel ilişkilerin etkisi altındadır. Bu çerçevede bireylerin kişisellik oluşturmaları sınırlı düzeyde kalmaktadır (Duman, 2012: 22). Geleneksel değerlerle çerçevelenmiş ailede, bireylerin ne zaman ve kiminle evleneceği, çocuk sahibi olmayı, aile üyelerinin konumu ve rolleri, aile üyeleriyle olan ilişkilerin ş̧ekillendiği ve önceden belirlendiği bir sistem sunmaktadır. Bireylerin, bu sistem çerçevesinde şekillenen değerleri sorgulamaları imkânsız bir hal almaktadır.

Toplumsal farklılaşma sonucu, geleneksel toplum yapılarının kısmen ortadan kalkması ya da zayıflaması bireyi eski toplumsal yapılardan kurtarıyor ve büyük bir özgürlüğe kavuşturuyor. Bu çerçevede bireycilleşmeden söz edilmektedir. Çok farklı grupların kesişme noktası haline gelen modern birey, gittikçe kendini özerk bir varlık olarak görmekte ve çevresini kuşatan toplumsal yapılarla hakiki bağlar kuramamaktadır. Bireyin çevresiyle sahih bağlar kuramama duygusu toplumda bürokratik örgütlerin egemenliği arttıkça daha da güçlenmektedir. Bireyin bu örgütlerle kurduğu ilişkiler salt araçsal ve biçimseldir (Loo ve Reijen, 2006: 19). Geleneğin bu dönüşümü

Turkish Studies - Social, 15(4) 
modernliğe özgüdür ve modern toplumla modernlik öncesi toplumla arasında ayrımda önemli bir yer kaplar. Yanı sıra dönüşüm, modernizmin bürokratik, ticari ve teknolojik sistemleri tarafindan kurumsallaştırılır (Giddens ve Pierson, 2001: 29). Sanayileşmenin, kentleşmenin, sekülerleşmenin söz konusu olduğu günümüz modern toplumlarında, bireysellikten, ikincil ilişkiler ve geleneksellikten uzak seküler ilişkilerin hakim olduğu gözlemlenmektedir. Bu durumu toplumsal olarak her alanda görebildiğimiz gibi toplumun en küçük birimi olan aile ve ailevi ilişkilerde de görmek mümkündür.

Bireycilik köklerini insanların günlük yaşamından, yaşamlarını kazanış biçimlerinden ve siyasal yaşamda başkalarıyla ilişki kurma biçimlerinden almaya başlar. Bireycilik akla yatkın tek bakış açısına dönüşür ki onu başlatan atalarımız için böyle olmadığı kesin (Taylor, 2011: 52). Bireyselleşme, insanların biyografisi, geleneksel ilkelerden ve güvencelerden, yabancı kontrollerden ve bölge üstü geleneksel kurallardan kurtarılmış, açık, isteğe bağlı ve görev olarak her bireyin eylemine verilmiştir. Aile olarak karara kapalı yaşam imkânlarının oranı giderek azalıyor ve karara açık, kendi kendini oluşturabilen biyografisinin oranı artmaktadır (Beck ve Beck-Gernsheim, 2012: 17-18). Geleneksel değerlerden arındırılan modern toplumlarda artık ailenin, evliliğin, aile üyeleri arasındaki ilişkilerin ve rollerinin, ev işinin yapısını değiş̧irdiği görülmektedir.

Geleneksellikten arındırılan modern toplumda bireysellik süreci, çekirdek ailenin sınırlarını belirginleştirmiştir. Ev kadınının çalışma hayatında yer alması, teknolojik gelişmeler ev işlerini de hafifletmiştir. Ev içi işlerin niteliksizleşmesi kadını, ev dışı mesleki çalışmalara yönlendirmiştir. Geleneksel toplumlarda ev içi emek ve bu çerçevede kadına biçilen rollerin daha önceden belirlenmesi, tartışmasız yerine getirilmesini gerektirmekteydi. Gelinen noktada, aile, ebeveynlik, aile içi ilişki ve roller sorgulanmaktadır. Daha önceden belirlenemez, sorgulanamaz değerlerin yerini, bireysellik almış, bireyden bireye hatta ilişkiden iliş̧iye değişen değerler ortaya çıkmıştır. Giderek artan oranda kendi yaşam biçimlerini belirleyen, başka bir ifadeyle yaşamlarının kanun koyucuları olarak geçmişin geleneklerinden kopan bireylerin birliktelikleri karşımıza çıkmaktadır. Kiminle evleneceği ya da birlikte yaşayacağı, nasıl yaşayacağı, ev içi rol ve statüleri, evliliği nasıl sürdüreceği, çocuk sahibi olup olmayacağı bireylerin karar ve sorumlulukları dâhilinde yer almaktadır.

Çocuk sahibi olmak başka bir varlığın rahat ve huzurunu riske atan bir durum olarak karşımıza çıkmaktadır. Mesleki hedefler ve kariyer planlarının feda edilmesi anlamını taşımaktadır. Aynı zamanda çocuk sahibi olmak sonzsuz bir bağlanmayı da kabul etmek demektir. Bununla birlikte doğum sonrası depresyon ve evliliklerde yaşanan krizler, modern toplumun sorunları arasında yer almaktadır (Bauman, 2012a). Geleneksel ailelerde belirlenen roller çerçevesinde çocuk dünyaya getirme tartışmasız ailenin sorumluluğunda olan bir durumdur. Fakat günümüz modern ailelerinde sınırlı sayıda çocuk dünya getirmek ya da çocuk sahibi olup olmama konusunda karar ve sorumluluk bireylere ait bir durum olarak karşımıza çıkmaktadır. Anneliğin, kadının en güçlü ve bağımlı rolü konumundayken; günümüz dünyasında çocuk sahibi olmak rahat ve huzurun ortadan kalkması, kariyer hedeflerine konan bir engel, fiziki deformasyon ve ağır sorumluluk kaynağı olarak değerlendirilmektedir. Evlenirken verilen "bir ömür boyu" sözü, çocuk sahibi olma sorumluluğu, aileye biçilen rol ve statüler, günümüz birliktelikleri için korkulan ve bağlayıcıllı̆̆ çok yüksek bir durum olarak karşımıza çıkmaktadır. Bireysellik sürecinde aile kurmak, aileye ilişkin değer ve sorumlulukları yüklenmek bireylere ait karar çerçevesinde değerlendirilmektedir. Dolayısıyla geleneksel değerlerden arınan modern toplumlarda çekirdek ailenin konumu, bireysellik ekseninde değişime uğramaya başladığı açıktır. Geleneksel değerler çerçevesinde kutsanan, tartışmasız kabul edilen rol ve statüler, günümüz dünyasında tartışmaya açık, sorgulanan, üzerinde anlaşmaya varılmaya çalışılan bir konumda yer almaktadır. Bireysellik çerçevesinde karakterize edilen aile kurumu, evlilik süreci ve evliliği ayakta tutan sorumluk ve roller en nihayetinde belirsizlik arz etmekte ve bu haliyle de ailenin güven kokan ortamı tehlikeye 
girmektedir. $\mathrm{Bu}$ anlamda çekirdek ailenin değişime uğramaya başladığı ve bu çerçeveden bakıldığında risk altında olduğu görülmektedir.

\section{Belirsizliğin Gölgesinde ve Güven-Güvensizlik İkileminde Aile}

Kadınlar ve erkekler bugün nikâhsız evlilik, boşanma, sözleşmeli evlilik yoluyla bir arayış, zorunlu bir arayış içinde, meslek ve aileyi, aşk ve evliliği bir arada yürütmenin savaşını veriyorlar. Yeni annelik ve babalık, arkadaşlık ve tanışıklık biçimleri geliştirmeye çalışıyorlar. Bütün bunlar geri döndürülemez bir biçimde harekete geçmiş durumda. Geleneksel sosyal kimliklerin zayıflamasıyla birlikte şahsiliğin merkezinde, erkekler ve kadınlar arasındaki cinsiyet rollerinin çelişkileri ortaya çıktı. Bunlar toplumu hem arka hem de ön planda değiştirmeye başladılar. Modern hayata geçiş sürecinde evlilik ilişkisinin yeni bir biçiminin nasıl adım adım geliştiğini de gösteriyor. Ömür boyu birbirine bağlananların söz hakları giderek arttı. Artık aileler bir araya getirip bağlamıyordu eşleri, tersine onlar birbirini seçiyordu. Kadın ile erkek arasındaki bağ artık dışarıdan genel kriterlere göre uygun bulunup kurulan dışsal bir bağ değil; bunun yerine artık iki insan arasında kurulan duyguya dayalı bir bağ, içten ve içeriden kurulan bir ilişki; eşler artık sınıfsal ve ekonomik koşulların boyunduruğundan kurtuldular ve meşruluk için tek bir ölçütte karar k1ldılar: kalbin sesi (Beck ve Beck-Gernsheim, 2012: 12,161). Modern toplumda evlilik, aile ilişkileri bireylerin kararları, bireylerin sorumlulukları ve birbirlerine verdikleri sözler eşliğinde gerçekleşmektedir. Dolayısıyla bu durum evlilikte ve aile ilişkilerinde farklı sorunların merkezi haline gelmektedir.

Modern sonrası dönemde bireyin varoluşu için birçok farklı durumlarda tatmini önemli hale gelmektedir. Kendi hayatlarını karakterize eden bireyler, çıkarlarına ters gelecek herhangi bir durumu reddetmek ve çıkarına uygun olan duruma yönelmesi büyük bir ihtimal olarak karşımıza çıkmaktadır (Akalın, 2017). İlişkide olma durumu sonsuza dek şöyle dursun sürekli ilişkide olma durumu onları tereddüde düşürüyor. Bunun onlara yükümlülük dayatmasından ve bask1 uygulamasından çekiniyorlar, böyle bir şeye ne dayanabiliyorlar ne de hazır hissediyorlar kendilerini. İlişki kurmak için ihtiyaç duydukları özgürlüğü ciddi bir biçimde sınırlandırabileceğini düşünüyorlar (Bauman, 2012a: 8). Evliliği yürütecek olan bireylerin kaygıları neticesinde ya aile kurma yolunu tercih etmemekte ya da belirli bir sözleşme yoluna tecih etmektedir. Bu durum esasında, modern dünyanın dönüştürmüş olduğu ailenin özünde, hesaplanamaz durumlar ve güven problemi yatmaktadır.

Hepimiz kararlar vermek zorundayı, ama bir zamanlar bir hesap meselesi olduğunu düşündüğümüz şey bugün artık bize hesaplanamamazlık meselesi gibi görünüyor. Belli ki bilgi, karşı karşıya bulunduğumuz riski tahmin edebileceğimize dair olumlu bir inanca sahip olmaktan bizi uzaklaştırmıştır (Giddens ve Pierson, 2001: 93). Dünya risk toplumunda veya küresel risk toplumunda yaşamak, daha önceki nesillerin karşılaşmadığı ekolojik risklerle karşı karşıya olduğumuz gibi, güvenliğimizle ilgili risklerle karşı karşıya olduğumuz bir toplumda yaşadığımız anlamına gelir (Kovacevic ve Kovacevic, 2017: 41).

Modernliğin üretmiş olduğu riskler aile için de geçerlidir. Aile kurmak ya da aileye dair görev ve sorumlulukları yüklenmek modern bireylerin uzak durduğu bir konu halini almaktadır. Ailenin geleceğini bugünden kestirmek zordur. Fakat yaşadığı dönüşüm, bireyselleşmenin aile üzerindeki etkisi, boşanma oranlarındaki artış, aile kurmama, birlikte yaşama deneyimleri aile nereye gidiyor sorusunu sormamıza neden olmaktadır. Aile kurumunun eskisi kadar sağlam temeller üzerine kurulmadığı, cazibesini ve kutsallığını yitirdiği görülmektedir. Geniş aile tipinin gittikçe küçüldüğü, eş seçiminde aile üyelerinin rollerinin azaldığı, evlilik sürecinde alınan görev ve sorumlulukların bireylere bırakıldığ 1 ve tartışma konusu haline geldiği, evliliklerin günlük hatta saatlik olmaya başladığı görülmektedir. Geleneksel değerlerin kutsadığı, rol ve statülerin önceden belirli olduğu ve tartışma konusu olmadığ 1 durumlar, artık bireylerin seçim ve kararına bırakılmaktadır. Bireyselliğin hâkim olduğu günümüz ailesinde istikrar ve güvenin aranan bir durum halini aldığg, belirsizliğin ve hesaplanamaz durumların hâkim olduğu görülmektedir.

Turkish Studies - Social, 15(4) 
Bireysellik ve bireysel kararlar eşiğinde şekillenen aile ve evlilik, belirsizlik arz etmektedir. Başka bir ifadeyle, kişiden kişiye, ilişkiden ilişkiye değişen değerler, geleneksel değerlerin netliğinin aksine, belirsizlik ve hesaplanamaz durumlarla aile kurumunu kuşatmıştır. Bunun dışında geleneksel değerler çerçevesinde şekillenen ailede, aile içi rol ve statüler, görev ve sorumluluklar, gerçekleştirilen evliliklerin ömrü, genellikle geleneklerin garantisi altında sürdürülmekteydi. Fakat bireyselliğin hâkim olduğu günümüz toplumlarında, aile içi rol ve statüler, görev ve sorumluluklar, evliliğin ömrü geleneksel değerlerin garantisi dışında, bireysel kararlar çerçevesinde güvensiz bir yapı sergilemektedir. Başka bir ifadeyle, artık ömür boyu süren evliliklerin garantisi dışında, ne zaman biteceği sorusuyla güven problemi yaşanan evlilikler gündeme gelmektedir. $\mathrm{Bu}$ yapı itibariyle boşanan, aile kurmanın gerekliliğini düşünmeyen, sadece birlikte yaşamayı tercih eden bireylerin varlığ 1 , kuşkusuz aile kurumunu ve geleceğini tehdit emektedir. Dolayısıyla bireysellik, belirsizlik, hesaplanamamazlık ve güvensizlikle küreselleşmenin risklerinin, aile kurmunu da etkisi altına aldığı görülmektedir.

\section{Türkiye'de Aile: Risk Altındaki Bir Kurum mudur?}

Ailenin Türkiye'deki gelişim seyri geleneksel geniş aileden modern çekirdek aileye doğru gerçekleşmiştir. Türk aile yaşamında çekirdek aile egemen bir konuma gelmiş, son yasal düzenlemelerle ailede kadın-erkek eşitliği ve yetkinin ortak paylaşımı kabul edilmiştir. Kadının iş yaşamına atılması, doğum oranını düşürmüş, kent ailesinin nüfusu kırsal kesim ailesine oranla azalmış ve ortalama 5 kişiye inmiştir (Akyüz, 2008: 140). Nitekim daha çok tarımsal yapı ile uyum içerisinde olan geniş aile, 1973 'te 32.4 'ten 2015 'te 16.5 e gerilemiştir. Çekirdek aile düzenli artış göstererek 1973'te yüzde 59'dan 2015 y1lında yüzde 66.9'a yükselmiştir. Parçalanmış ailelerde de düzenli bir artış söz konusudur. Türkiye'de çekirdek aile iki ve daha az çocuklu bir hüviyet kazanmaktadır. Zira çekirdek ailenin artışına paralel olarak üç ve daha fazla çocuklu aileler azalırken iki ve daha fazla çocuklu çekirdek aileler artmaktadır (Bozkurt, 2018: 285-286).

Sanayileşme, kentleşme, teknolojik gelişmeler, kırdan kente yaşanan göç deneyimi, eğitim oranlarındaki artış ve en nihayetinde emek piyasasında kadınlarında yer almaya başlaması, dünyada olduğu gibi Türkiye'de de aile kurumunun gelişim seyrini değiştirmiştir. Geleneksel kurallar çerçevesinde belirlenen rol ve statülerin, yeni bir form aldığı söylenebilir. Geniş aileden çekirdek aileye dönüşümün ötesinde, çekirdek ailede de belli başlı değişimlerin yaşanmasına neden olmuştur. Özellikle boşanma oranlarındaki artış ciddi boyutlara ulaşmıştır. Türkiye İstatistik kurumunun 2019 yılına ilişkin evlenme ve boşanma oranlarına göre, 2019'da evlenen çiftlerin sayıs1 2018 yılına göre yüzde 2,3 azalarak 541 bin 424'e geriledi. Evlenme hızı binde 6,56 olarak gerçekleşti. 2019'da boşanma sayısı 2018'e göre yüzde 8 artarak 155 bin 47'ye yükseldi. Boşanma hızı binde 1,88 oldu. Ortalama ilk evlenme yaşı 2019 'da erkekler için 27,9 , kadınlar için 25 olarak kaydedildi (TUIK, 2019).

Türkiye'de evliliğe ilişkin tutumların dönüşümde olduğu bir dönem yaşanmaktadır. Hiç evlenmemişler ve boşanmışların oranı artmakta, ilk evlenme yaşı yükselmektedir. Aşkın evlilik için önemli bir beklenti ve koşula dönüşmesi de bunun bir göstergesidir. Bu dönüşümde eğitim ve sosyo-ekonomik statü önemli bir rol oynamaktadır. Eğitim seviyesi yükseldikçe evlenme ertelenmektedir. Eğitim ve sosyo-ekonomik statï seviyesi yüksek olan gruplarda hiç evlenmemişlerin oranı da yükselmektedir. Bireyler sosyo-ekonomik statü ve eğitimleri ve aileden gelen baskılar nedeniyle evlenmek yerine, evlilikte kendi tercihlerini gerçekleştirmeyi öne çıarmaktadırlar (Turgut ve Feyzioğlu, 2014: 167). Eskiden aileler ayrılma yoluyla da bozulmaktayd1, ancak boşanmak sadece zenginler için mümkün olmaktaydı. Modern toplumda boşanma oranlarının artmış olması herşeyden önce nüfusun çoğunluğunun resmen ayrılabilmesini ve boşanabilmesini sağlayan yasal değişikliklerin göstergesidir. Bu durum eş ve çocukların eskiden olduğundan daha fazla ekonomik güvenceye sahip oldukları anlamına gelmektedir (Gittins, 2012: 152). Artan boşanma oranları, çekirdek ailenin de geleneksel bağlardan koptuğu, boşanmaya karş1 olumsuz algı ve tutumların çözüldüğü görülmektedir. Bu durum ise, ömür boyu süren evliliklerin 
günümüzde kaygan bir zeminde yer aldığını göstermektedir. $\mathrm{Bu}$ anlamda evlilik ve ailenin sürdürülmesindeki kırılganlık her geçen gün artmaktadır. Boşanma oranlarındaki artışa paralel olarak evlenme oranlarındaki ciddi düşüşler, Türkiye'de de aile kurumunun çözülmeye başladığının göstergesidir. Evlilik ve aileye alternatif olarak birlikte yaşama deneyimleri, toplumsal olarak aile kurma gerekliliği fikrinin zayıfladığını göstermektedir.

Çekirdek ailenin çekirdeki, tözsel anlamda bir öze, yaşamın sürekliliği anlamında kurucu bir özneye ya da tohuma ve metafor olarak ise, diğer toplumsal değişmelere uygun olarak tüketilmeye müsait bir gerçekliğe göndermede bulunur. Kurumların içeriklerinin farklılaşması, kültürel ya da toplumda meydana gelen yapısal ve ontolojik değişimlerle mutlaka yakından ilgilidir. Çekirdek ailenin çerezleşmesi bu anlamda, kurucu özne gerçekliğinin taklidi olarak hipergerçekliği önceleyen yani üretici niteliğiyle tohum metaforunun yerine taklidini kurgulayarak tüketilen çerez metaforunu yerleştirmektir. Dolayısıyla postmodern toplumda çerez aile, çözülen, parçalanmış ve tamamlanmamış nitelikleriyle yapısının ve gerçekliğinin hastalık arz ettiği bir algıdır. Ailenin problemleri olan boşanma, nikâhsız birlikte yaşama ve tek anne-babalı aile gibi durumlara karşı ailenin işlevlerini kaybettiği düşüncesinin hipergerçeklik bir tutumla anlaşılma girişimidir. Böylelikle çekirdek olma niteliği, tohumsallıktan kurtulup bilinçsizce tüketilen ve bir eğlence malzemesine dönüştürülen çereze ya da kuruyemişe işaret etmektedir (Can, 2019: 56-57). Geleneksel bağlardan kopuşlar, bireye eski kontrollerden ve sorumluluklardan kurtulma olanağ vermiştir. Geleneksel rol ve statülerden özgürleştirilmiş olan kadın, özellikle emek piyasalarında yer alarak erkeğin ekonomik güvencesinin ömür boyu garantisi dışına çıkmıştır. Ekonomik olarak bağımsızlaşan kadın, geleneksel değerlerden kopuş ve nihayetinde aile ve evlilik sürecine yeni form veren dinamizmi oluşturmaktadır. Ailenin kendine ait formu ve kuralları sorgulanarak anlaşma nesnesi haline getirilmesi, ailenin geleceğini ve evlilik süresini bireylerin kararı eşiğine bırakmıştır. Başka bir ifadeyle, geleneksel ailenin aksine modernleşmenin getirisi olan bireysellik; evlilik, evlilik süresi, evlilik ilişkileri, rol ve statüler, feshedilebilir özelliği ile aile, bir sözleşme formunu almaktadır. $\mathrm{Bu}$ durum ise, nihayetinde ailenin kendine has formu ya da içsel dinamizminin sorgulanarak çözülmesine neden olmaktadır.

Geleneksel değer ve roller çerçevesinde kuralları şekillenen aile, aile fertlerine ve bireylere güven veren koşullar sunmaktaydı. Güven ve koruma sunan aile, bugün bireysel yaşama, bireysel karar alma ve ailenin vermiş olduğu sorumluluk duygusundan kurtulma isteği, bireylere güvenlik duygusu veren koşulları ortadan kaldırmıştır. Bireyden bireye, ilişkiden ilişkiye değişiklik gösteren değerler ekseninde şekillenen aile, geleneksel değerlerin aksine evlilik süresi, evlilik içi ilişkiler, görev ve sorumluluklar belirsizlik arz etmektedir. Nihayetinde geleneksel değerlerin netliğinden ve uzun ömürlü ilişkilerden bahsetmek yerine, bireysel kararlar çerçevesinde şekillenen aile ve evliliğin ne kadar süreceğinin hasaplanması güçleşmekte ve dolayısıyla güvensizlik arz eden bir yap1 sergilemektedir. Güvenlik duygusunun ortadan kalkmas1, aile kurma gerekliliğini ortadan kaldırmaktadır. Başka bir ifadeyle, bireyselliğin etkisiyle ailenin yeni form alması, ya da aile kurma gerekliliğinin zayıflaması, ailenin geleceğinin ne oranda risk altında olduğunu sorgulatmaktadır. Dünyada olduğu gibi Türkiye'de de aile, küreselleşmenin risklerinden etkilenmektedir. Risklerden etkilenme oranları her ülkenin kendi içsel dinamizmine bağlı olarak değişmektedir. Türkiye'de aile hala başat konumda varlığını sürdürmektedir. Fakat bireysellik, yapılan evliliklerin feshedilebilir sözleşme niteliği alması, bireysel yaşama isteği, birlikte yaşama deneyimleri Türkiye'de aile kurumunu olumsuz yönde etkilemektedir. Özellikle boşanma oranlarındaki artışlar, evlilik oranlarındaki hızlı düşüşler, söz konusu durumu destekler niteliktedir. Türkiye'de ailenin kutsallığ devam etmekle birlikte, yaşanan dönüşümlerden etkilenerek ailenin kendine özgü dinamizminin sorgulanması, içsel bir tehdit olarak görülmektedir.

\section{Sonuç}

Toplumların değişim dinamiğini her şeyden önce modern ekonomik düzen oluşturmaktadır. Modernlik esasında sadece değişimin kendisi değildir, aynı zamanda akılcı, bilimsel, teknolojik ve 
siyasi örgütlenmelerin de yaygınlaşması demektir. $\mathrm{Bu}$ niteliklerin yaygınlaşması ile birlikte modernlik, çok daha dinamik bir toplumsal yapıya sahiptir. Dinamik yapı toplumsal olarak risklerin üretilmesinde de önemli bir etkiye sahiptir. Teknolojik gelişmeler sayesinde gelişen soyut sistemler ve uzmanlık alanlarında çeşitlilik, karşılaşılabilecek durumlara karşı önlem almada önemli bir avantaj sağlamaktadır, fakat bir taraftan da küresel risklerle karşı karşıya olduğumuz bir çağda yaşamaktayız. Söz konusu risklerle mücadelenin bireysel boyutlarının yüksek olduğu görülmektedir. Modernliğin en önemli getirisi olan bireysellik, risklerle karşılaşmada önemli bir paya sahiptir. Dünya risk toplumunda yaşamak demek, daha önceki kuşakların karşılaşmadığı risklerle karşılaştığımız ya da karşılaşacağımız anlamına gelmektedir. Bir zamanların hesap meselesi olan riskler, artık hesap meselesi dışına çıkmış, riskleri tahmin etme gibi bir olumlu inançtan uzaklaştırmış. Üstelik bireysel karar mekanizması dâhilinde yer alan riskler, güvensiz bir ortam oluşturarak insanlığ ciddi boyutlarda tehdit etmektedir. Küresel riskler sadece ekolojik, ekonomik ya da siyasi boyutları ile değil, aynı zamanda toplumsal sonuçları ile de tehdit etmektedir. Bu alanlardan birisini ise ailenin değişiminde ortaya çıkacak riskler oluşturmaktadır.

Aile yaşamı, belirli kurallar, gelenekler, adetler çerçevesinde belirli bir düzene sahiptir. Aile içerisinde yaşamını sürdüren bireyler, kurallar çerçevesinde rol ve statü edinmektedirler. Biyolojik, psikolojik, sosyolojik ve ekonomik görevleri bulunan ailede, rol ve görevler tartışmasız bir şekilde herkes tarafından bilinip, uygulandığı bir sistem üzerine kuruludur. Fakat artık ailenin eski sağlamlığını, cazibesini ve kutsallığını yitirdiği görülmektedir. Modern toplumsal yaşam geleneklere, alışkanlıklara, adetlere ve inançlara bağlı olmayan bir toplum oluşturmaktadır. Geleneksel bağlardan kopuş, bireye eski kontrollerden kurtulma olanağı vermiştir. Evlilik sürecinde alınan görev ve sorumlulukların geleneksel ailelerde olduğu gibi önceden herkesin kabul ettiği bir yapının aksine, üzerinde konuşularak anlaşmaya varılacak bir sözleşme durumunu almıştır. Aile içerisindeki ilişki süreçlerinin değişimi ile birlikte, aile kurumu ile ilgili önemli değişimlerde yaşanmaktadır. Bireyselliğin hâkim olduğu günümüz toplumlarında aile kurmakta alınan bireysel kararların yanı sıra, boşanma oranlarındaki artı̧̧lar, aile kurmak yerine birlikte yaşama deneyimlerinin yüksek olduğu görülmektedir.

Bireyselliğin hâkim olduğu günümüz ailesinde istikrar ve güvenin aranan bir durum halini aldığı, belirsizliğin ve hesaplanamaz durumların hâkim olduğu görülmektedir. Nitekim risk toplumunun teknolojik, ekonomik, soyut sistemler üzerinde görülen risklerin, hesaplanamaz durumların, belirsizliklerin ve güven probleminin, toplumsal boyutlarının da olduğu görülmektedir. Özellikle bireyselleşmenin dönüştürmüş olduğu günümüz ailesinde, belirsizlik, hesaplanamazlık, bireysellik, güven problemi bulunmaktadır. Ailenin varlığı tartışmasız devam etmektedir, fakat geleneksel bağlardan kurtulan aile, bireyselliğin ve bireysel kararların sınırları içerisinde yer almaktadır. Söz konusu sınırlarlar ise, aile kurumu ve bireyler için kaygan bir zemin oluşturmaktadır. Kaygan zemin ise aile kurumunu, evlilliğin ömrünü ve evlilik ilişkilerini olumsuz yönde etkilediği açıktır. Kişiden kişiye, ilişkiden ilişkiye değişen değerler, geleneksel değerlerin netliğinin aksine, belirsizlik ve hesaplanamaz durumlarla aile kurumunu kuşatmıştır. Bunun dışında geleneksel değerler çerçevesinde şekillenen ailede, aile içi rol ve statüler, görev ve sorumluluklar, gerçekleştirilen evliliklerin ömrü, genellikle geleneklerin garantisi altında sürdürülmekteydi. Fakat bireyselliğin hâkim olduğu günümüz toplumlarında, aile içi rol ve statüler, görev ve sorumluluklar, evliliğin ömrü geleneksel değerlerin garantisi dışında, bireysel kararlar çerçevesinde güvensiz bir yapı sergilemektedir. Başka bir ifadeyle, artık ömür boyu süren evliliklerin garantisi dışında, ne zaman biteceği sorusuyla güven problemi yaşanan evlilikler gündeme gelmektedir. $\mathrm{Bu}$ yap1 itibariyle boşanan, aile kurmanın gerekliliğini düşünmeyen, sadece birlikte yaşamayı tercih eden bireylerin varlığı, kuşkusuz aile kurumunu ve geleceğini tehdit emektedir. Dolayısıyla bu güvensizlik ise aile kurumu için, küreselleşmenin risklerine kapı araladığı açıktır.

Küreselleşmenin riskleri, her kurum ve her toplum için farklı aşamalarda gelişim seyri izlediği gibi, aile kurumunun geleceği ise, her toplumun, her ülkenin kendi içsel dinamiğine göre gelişim seyri izleyerek risk boyutu farklılaşmaktadır. Türkiye'de aile kurumu kutsallığını sürdüren 
bir konumda yer almasına karşın, bireyselliğin kaygan zemininde ailenin içsel dinamizminin sorgulanması, çözülmelere kapı araladığı bir gerçektir. Evlilik gerçekleştirilse bile, bireysel kararlar çerçevesinde güven ortamının aşınmasından dolayı uzun süren evliliklerden bahsetmek mümkün değildir. Boşanma oranlarındaki artışlar, evlilik yaşının yükselmesi, aşkın evlilik için önemli bir kriter konumunda yer alması, yaşanan dönüşümlerin önemli bir ayağını oluşturmaktadır. Bu dönüşümde sosyo-ekonomik statü, eğitim seviyesindeki artış, kadının çalışma yaşamında yer alması evlilik oranlarını etkilerken, evlilikte bireyler, kendi tercihlerini ön plana çıkarmaktadır. Aile kurumuna alternatif olarak birlikte yaşama deneyimleri, evlilik yapma gerekliliğini yavaş yavaş ortadan kaldırmaktadır. Dolayısıyla Türkiye'deki aile kurumu, küreselleşmenin risklerinden kendine düşen payı almaktadır.

\section{Kaynakça}

Akalın, R. C. (2017). "Ulrich Beck'in risk toplumu kavramsallaştırması ekseninde toplumsal kontrolün dönüşümüne giriş denemesi”, Medeniyet ve Toplum Dergisi, 1(1), 35-54.

Akyüz, H. (2008). Kurumlar sosyolojisi tanımlar, kuramlar ve uygulamalar, Siyasal Kitabevi Yayınları.

Bauman, Z. (2012a). Akışkan aşk. Işık Ergüden (Çev), Versus Yayınları.

Bauman, Z. (2014b). Modernite, kapitalizm, sosyalim-küresel çağda sosyal eşitsizlik. F. Doruk Ergun (Çev). Say Yayınları.

Beck, U. (2011). Risk toplumu/Başka bir modernliğe doğru. Kazım Özdoğan ve Bülent Doğan (Çev), İthaki Yayınları.

Beck, U., Beck - Gernsheim,E. (2012). Aşkın normal kaosu, Nafer Ermiş (Çev), İmge Kitabevi Yayınları.

Bozkurt, V. (2018). Değişsen dünyada sosyoloji temeller kavramlar kurumlar, Ekin Yayınevi Yayınları.

Can, İ. (2019). "Moderniteden postmoderniteye ailenin ontolojisi ya da modern çekirdek aile çerezleşiyor mu?", Aydın, M. (Ed.) Aile Sosyolojisi Yazıları (ss. 51-81). Açılım Kitabevi Yayınları.

Doltaş, D. (2003). Postmodernizm ve eleştirisi, İnkılap Yayınları.

Duman, M. Z. (2012). “Aile kurumu üzerine tarihsel bir okuma girişimi ve muhafazakâr ideolojinin aileye bakışı”, Insan ve Toplum Bilimleri Araştırmaları Dergisi, 1(2), 19-51.

Giddens, A. (2010a). Modernite ve bireysel kimlik: geç modern çağda benlik ve toplum. Ümit Tatlıcan (Çev), Say Yayınları.

Giddens, A. (2013b). Sosyolojide başlangıç okumaları. Günseli Altaylar (Çev), Say Yayınları.

Giddens, A., Pierson, C. (2001). Söyleşiler-Modernliği anlamlandırmak. Serhat Uyurkulak ve Murat Sağlam (Çev), Alfa Yayınları.

Gittins, D. (2012). Aile sorgulanıyor. Tuna Erdem (Çev), Pencere Yayınları.

Karataş, K. (2011). “Toplumsal değişme ve aile”, Toplum ve Sosyal Hizmet, 12(2), 89-98.

Kovacevic, B., Kovacevic, I. (2017). Sociology of global risk society (Anthony Giddens and Ulrich Beck). Banca Luka.

Loo, H.V.D., Reijen, W. V. (2006). Modernleşmenin paradoksları. Kadir Canatan (Çev), İnsan Yayınları.

Turkish Studies - Social, 15(4) 
Özkiraz, A., İşçi-Baş, G. (2016). "Osmanlıdan günümüze Türk toplumunda aile yapısı ve boşanma”, KMÜ Sosyal ve Ekonomik Araştırmalar Dergisi, 18 (30), 87 - 95.

Mythen, G. (2004). Ulrich Beck a critical introduction to the risk society. Pluto Press.

Steger, M. B. (2004). Küreselleşme. Abdullah Ersoy (Çev), Dost Yayınları.

Taylor, C. (2011). Modernliğin sıkıntıları. Uğur Canbilen (Çev), Ayrıntı Yayınları.

Tekin-Epik, M., Çiçek, Ö., Altay, S. (2017). "Bir sosyal politika aracı olarak tarihsel süreçte ailenin değişen/değişmeyen rolleri”, Sosyal Politika Çalışmaları Dergisi, 35-59.

Tomlinson, J. (2004). Küreselleşme ve kültür. Arzu Ekber (Çev), Ayrıntı Yayınları.

Touraine, A. (2012). Modernliğin eleştirisi. Hülya Uğur Tanrı̈ver (Çev), YKY Yayınları.

Turgut, F. (2017). "Tarihsel süreçte aile kurumunun dönüşümü ve geleceğine yönelik çıkarımlar”, Medeniyet ve Toplum Dergisi, 1(1), 93-117.

Turgut, M., Feyzioğlu, S. (2014). Türkiye aile yapısı araştırması tespitler, öneriler. Aile ve Sosyal Politikalar Bakanlığ 1 Yayınları.

Ünal, V. (2013). "Geleneksel geniş aileden çekirdek aileye geçiş sürecinde boşanma sorunu ve din", Uluslararası Sosyal Araştırmalar Dergisi, 6(26). 588-602.

Wagner, P. (2013). Deneyim ve yorum olarak modernlik-modernliğin yeni sosyolojisi. İbrahim Kaya (Çev), Pegem Akademi Yayınları. 